\title{
바디롤러 운동과 요가의 복합처치가 중년여성 요통환자의 체력, 척추 변인 및 통증자각도에 미치는 영향 *
} 박해연 ${ }^{1)}$ - 김진홍 ${ }^{2)}$ - 강설중 ${ }^{1)}$ - 김병로 ${ }^{1 *}$

1) 창원대학교 2) 인제대학교 운동과학연구소

\begin{abstract}
Hae-Yeon Park · Jin-Hong Kim · Seol-Jung Kang • Byung-Roh Kim. Effect of Combined Treatment with Body Roller Exercise and Yoga on Physical Fitness, Variables Related Vertebral Column and VAS of Middle-aged Women with Chronic Low Back Pain. KINESIOLOGY, 2015, 17(4): 39-48. [PURPOSE] The purpose of this study was to investigate the effect of combined intervention of body roller exercise and yoga on physical fitness, variables relate vertebral column of middle aged women with chronic lower back pain. [METHODS] Forteen middle-aged women with chronic low back pain were divided into one of two groups, i.e., exercise group ( $n=7$, age 59.0 \pm 7.4 years) and control group ( $n=7$, age 53.1 \pm 8.5 years). Subjects in exercise group went through body roller exercise and Yoga for $40 \mathrm{~min}$ and $20 \mathrm{~min}$ per session, respectively. Yoga exercise was Trikonasana; Adho Mukha Svanasana; Bhujangasana; Supta Padangusthasana1, 2, 3; Eka Padaanda Rajakapotasana. The physical fitness, Cobb's angle, lumbar spine rotation, tilt shoulders, pelvis horizontal degrees, visual analogue scale (VAS) were measured and compared between pre- and post test. [RESULTS] Muscular endurance was significantly higher after the intervention compared in the exercise group. Lumbar spine rotation length, shoulder slope, VAS were significantly decreased after the intervention in exercise group. However, no significant interactions were observed in flexibility, Cobb's angle, and pelvis height. [CONCLUSIONS] Body rollers exercise and Yoga intervention improved positively in muscular endurance, spine rotation angle, tilt shoulders, and the VAS Index. In conclusion, data suggest that body rollers exercise and Yoga may be an effective intervention for patients with low back pain.
\end{abstract}

Key words : body roller exercise, yoga, cobb's angle, vas, strength, low back pain 주요어 : 바디롤러 운동, 요가, Cobb's 각, 통증자각도, 근력, 요통

\section{서론}

요통은 인간이 직립보행하면서 발생한 여러 가지 질 병 중에서 가장 대표적인 것이며 평생 동안 누구라도 한번쯤 않게 되는 흔한 질환이다 요통은 생활습관과 직업의 유형 등 직접적인 면과 척추를 지지하는 주변 근력이 수용할 수 없는 정도의 고강도 자극으로 인해 발생한다(Cailliet, 1995). 따라서 근력범위 이상의 외부 자극에도 잘 대처하고 일상생활을 자유롭게 유지할 수 있도록 요통예방을 위한 다양한 노력이 필요하다.

요통치료는 일시적 통증완화를 위한 소극적 방법 인 약물 및 물리치료 요법과, 요부의 근육, 건, 인대 강화와 요부의 구조적 변형을 억제하는 적극적 운동
요법 등을 들 수 있다(Kim et al., 1996).

척추주변의 근력, 근지구력, 유연성을 높이고 혈류 증 가를 유도하는 운동요법은 요통유발 손상부위의 회복과 예방에 효과가 있다(Jung et al., 2006). 척추근력강화에 주로 이용된 저항성운동 요법은 90년대부터 도구를 사 용하여 다양하게 실시되고 있다. 소위 광역 및 국소부위 근육을 타깃으로 복횡근, 내복사근 등 다열근과 심부근 육의 코어안정화 운동의 효과를 입증한 것이 그 근거로 들 수 있다(Danneels et al., 2000; Song et al., 2008). 또 한 직립보행하고 있는 인간의 척추에 중력의 작용을 최 소화 할 수 있는 닫힌 사슬운동과 슬링운동이 요통완화 와 예방에 기여한 것도 한 예로 확인할 수 있다(Lee, 2005; Nam et al., 2009; Park et al., 2009). 결국 문제는

\footnotetext{
* 이 논문은 2015년도 창원대학교 연구비에 의해 연구되었음.

** brkim@changwon.ac.kr
} 
인간의 척추를 감싸고 있는 표면근육(superficial muscle) 과 심부근육(deep muscle)을 어떻게 발달시키느냐에 달 려있다. 몇몇 선행연구를 보면 운동의 방법과 종류에 따 라 표면 및 심부근육에 미치는 영향이 서로 다르다는 근거하에 크런치, 골반기울임 운동, 엎드려 팔굽혀펴기 등의 체간근력운동과 측면교각운동, 복부끌어당기기 등 의 심부근육 안정화 운동이 요통 완화와 요부근력 강화 에 효과적인 것으로 보고되었다(Kooket et al., 2013).

한편 Shin(2014)은 전신저항운동(total resistance exercise)인 지면과 평행을 이루는 플랭크(plank) 동작을 근육동원이 많은 난이도와 자세의 안정성 정도에 따라 중심근육 안정화에 미치는 영향에 차이 있음을 보고하 였다. 이 연구를 토대로 근활성도의 효과를 극대화하기 위하여 동작의 난이도를 높이는 다양한 플랭크 동작을 추천하였다. 만성요통 개선에 다양한 강도의 적용이 가 능한 탄성밴드활용 운동요법(Kirkesola, 2001; Lee et al., 2010)과 골반균형 개선을 위한 미 플로리다 의대 척추 연구소 개발 메덱스(Medx) 운동 프로그램이 요부 및 복부 근력 증가의 효과가 입증되었다(Lee, 2005; Hyun et al., 2012). 이처럼 중량을 이용한 등장성 형태의 저 항성운동과 등척성운동이 포함된 요통체조를 병행 실시 하는 것이 근력증가와 골격의 결합조직 보호에 도움을 주는 것으로 보고되었다(Junget et al., 2006).

앞에 언급한 능동적인 저항운동요법과는 다른 수동 적인 스포츠마시지 요법도 20 30대 남녀의 다리의 각 도와 하지의 길이 교정에 효과가 있었으며, 요통자각지 수도 다소 감소하였다고 보고하였다(Pack et al., 2009). 그리고 30 40대 여성 요통환자를 대상으로 요부의 유 연성과 골반변위에 수동적인 카이로프랙틱을 처치한 그룹과 운동요법을 병행 처치한 그룹을 비교한 결과 운동요법을 병행 처치한 그룹이 더 효과적인 것으로 보고되었다(Kim et al., 2010). 이처럼 수동적이든 능동 적이든 요통개선과 예방을 위한 다양한 운동프로그램 의 효과는 유효한 것으로 이해할 수 있다.

요부 안정화 운동은 요부통증을 감소시키기 위해 관 절의 가동범위를 확대하여 요추주변의 심부근육을 단 련하는 것이다. 척추주변 근육을 강화하는 것은 운동과 일상생활을 할 때 척추관절의 수축과 이완시 심부근육 의 불안정한 반응이 낮아져 통증 유발을 억제하게 된 다(Kim et al., 2007). 통상적으로 정상인은 요추 주위
의 심부근육인 복횡근이 수축된 후 표면근육이 작용하 는 반면 요통환자는 심부 근육의 작용이 미미한 상태 에서 표면근육의 작용으로 일상적인 활동을 하는 특성 때문에 요통발생비율이 높다고 할 수 있다. 이러한 이 유로 인해 요통예방을 위해 심부근육을 강화하는 것이 중요하다(Hodges et al., 1997; Kook et al., 2013).

따라서 간단한 도구를 이용하여 능동적으로 통증부 위를 찾아 자극하고 심부근육 강화에 도움이 될 수 있는 바디롤러 운동요법과 호흡을 통한 긴장완화와 관절 가동범위 확대에 도움을 주는 아사나요가를 병 행 처치하여 만성요통을 개선해 보려는 시도는 의미 있을 것으로 생각된다. 특히, 이러한 방법은 요통환자 스스로가 간단한 소도구를 활용하여 요추주변의 심부 근육을 스스로 단련할 수 있는 기회를 갖게 되고 지 속적으로 실시할 때 운동의 효과가 있는 만큼 환자가 능동적으로 행할 수 있는 방법(Lee, 2015; Lim et al., 2003; Song, 2015)이라는 점에서 그 활용가치가 매우 높을 것으로 생각된다. 뿐만 아니라 아사나 요가는 요 통환자의 관절가동범위를 확대하고 척추주변의 근육 을 강화하는 효과도 기대할 수 있다(Kim, 2011). 그러 나 아직까지 소도구를 이용한 바디롤러 운동요법과 요가 요법의 병행처치가 요부의 통증 개선과 요부 안 정화에 얼마나 기여하는지는 잘 알려져 있지 않다.

이러한 배경에서 본 연구에서는 만성요통환자를 대 상으로 간단한 소도구를 이용하여 능동적으로 통증부 위를 찾아 자극하고 강화하는 바디롤러 요법과 아사 나요가를 병행 처치한 후 만성요통 환자의 체력, 척추 변인 및 통증자각도에 어떠한 변화가 있는지를 알아 보고자 하였다. 이를 통해 만성요통환자는 물론 운동 부족과 직업생활, 그리고 나쁜 생활습관 등으로 발생 되는 요통을 개선할 수 있는 운동프로그램을 구성하 는데 도움을 줄 수 있을 것으로 생각된다.

\section{연구방법}

\section{연구대상}

본 연구의 대상은 G도 J시 거주 40 60대 중년여성 
중 만성요통질환자를 무작위로 선정하였으며, 본인의 동의하에 $\mathrm{J}$ 시, 소재 $\mathrm{G}$ 재활의학과에서 전면과 측면 full spine PA X-ray 검사 후 전문의의 척주 이상 소견과 Cobb's angle 이상 소견을 보인 요통환자 14 명 중에서 운동그룹 7명과 통제그룹 7명으로 구분하였다.

모든 대상자의 연구진행절차는 인체실험윤리심의위 원회(Human Subject Committee)의 승인 하에 본 연 구의 목적과 내용을 충분히 설명 후 실험 참가에 대 한 동의를 받은 다음 연구를 진행하였다. 운동프로그 램의 지속 및 중단 여부는 대상자 자유의사에 따라 진행되었다. 연구대상자의 운동집단과 통제집단 간 변 인의 통계적 유의차는 없었으며, 신체적 특성은 <Table 1>에서 나타난 바와 같다.

Table 1. Physical characteristics of subjects $(\mathrm{M} \pm \mathrm{SD})$

\begin{tabular}{cccccc}
\hline Group & $\begin{array}{c}\text { Age } \\
(\mathrm{yrs})\end{array}$ & $\begin{array}{c}\text { PD } \\
(\mathrm{yrs})\end{array}$ & $\begin{array}{c}\text { Height } \\
(\mathrm{cm})\end{array}$ & $\begin{array}{c}\text { Weight } \\
(\mathrm{kg})\end{array}$ & $\begin{array}{c}\text { BMI } \\
\left(\mathrm{kg} / \mathrm{m}^{2}\right)\end{array}$ \\
\hline \hline EG & 59.00 & 14.86 & 159.22 & 61.32 & 21.00 \\
$(\mathrm{n}=7)$ & \pm 7.43 & \pm 7.13 & \pm 4.40 & \pm 8.20 & \pm 4.68 \\
\hline CG & $53.14 \pm 8$. & 10.71 & 159.27 & 61.30 & 20.59 \\
$(\mathrm{n}=7)$ & 53 & \pm 6.16 & \pm 3.26 & \pm 9.90 & \pm 4.92 \\
\hline
\end{tabular}

EG; exercise group, CG; control group, $\mathrm{PD}$; pain duration, $\mathrm{BMI}$; body mass index

\section{측정항목 및 방법}

\section{Flexibility and Muscular endurance}

유연성 측정은 $\operatorname{ACSM(2013)ㅇㅢ~guidelineㅇㅡㄹ~ㄱㅣㅈㅜㄴㅇㅡㄹㅗ~}$ 좌전굴(Sit and Reach) 테스트를 하였다. 측정방법은 피검자가 앉은 후 두 발꿈치를 측정 대 상자에 붙이고 발끝은 $5 \mathrm{~cm}$ 정도 넓힌 다음 두 손끝을 모아 손가락을 펴서 최대로 앞으로 굽혀 2초간 멈춘 후 측정하였으며, 2 회 $\mathrm{cm}$ 단위로 측정하여 좋은 기록을 선택하였다.

근지구력은 일정한 운동부하에 근 수축을 지속적으 로 수행할 수 있는 능력으로 윗몸 일으켜 정지하는 동작의 지속시간으로 하였다. 측정방법은 피험자가 수 평의 바닥에 누워 무릎을 직각으로 세운 뒤 상체를 일으켜 양손을 무릎에 닿게 한 다음 등이 바닥에 떨 어진 상태를 0.1 초 단위로 2회 측정하여 좋은 기록을 선택하였다.

\section{Cobb's angle}

운동프로그램 전 후 척추전면을 Full spine PA X-ray 검사 후 Cobb's angle을 측정하였다. Cobb's angle은 만 곡의 오목한 방향으로 가장 많이 기울어진 상, 하부의 척주 결정 후, 상하부 끝 척주의 하단에 기울기 연장선 을 긋고, 상하부의 아래위로 연장선과 직각이 되도록 선 을 그어 교차된 상하부 각을 측정하였다<Figure 1>.
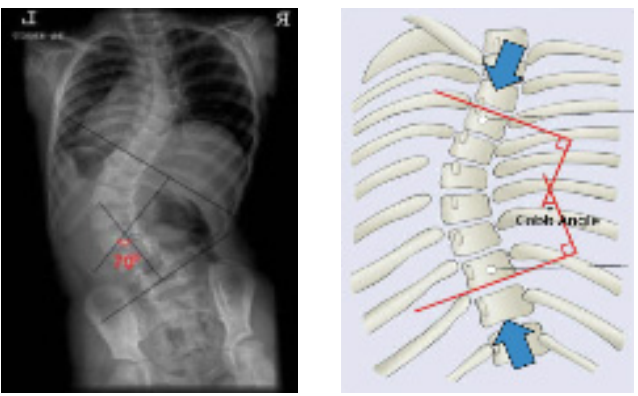

Figure 1. Cobb's angle

척추 회전길이

척추 회전길이는 후면에서는 경추 2 번 치상부위 (dens)의 정점과 골반의 치골결합(pubic symphysis)의 중앙을 연결하는 중심선을 기준으로 하여 골반의 좌. 우측 전위 정도가 중심선에서 벗어난 길이를 $\mathrm{mm}$ 단위 로 측정하였다<Figure 2>.

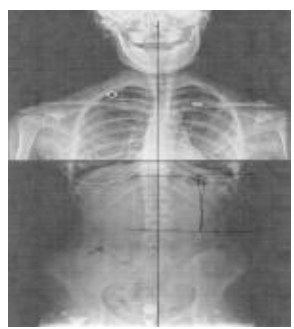

Figure 2. Lumbar spine rotation length

어깨 기울기

어깨 기울기 측정은 <Figure $3>$ 에서 보는 바와 같 이 좌우양측 견봉을 직선으로 표시하고, 신체의 시상 면 정중앙선과 직각으로 수평선을 표시한 후 좌우 견 봉 선과 수평선 간의 차이를 $\mathrm{mm}$ 단위로 측정 하였다. 


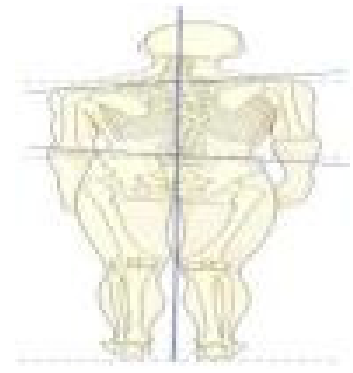

Figure 3. Shoulder slope \& Pelvis height

\section{골반 높이}

Full spine PA X-ray 검사자료를 바탕으로 <Figure 3>에서 보는 바와 같이 좌우양측 장골능을 직선으로 표시하고, 신체의 시상면 정중앙선과 직각으로 수평선 을 표시한 후 좌우 장골능 선과 수평선간의 차이를 $\mathrm{mm}$ 단위로 측정 하였다.

\section{통증자각도 (Visual Analogue Scale; VAS)}

12 주 운동프로그램 전, 후 Huskisson에 고안된 통 증지수(Visual Analogue Scale; VAS) 표에 실험 참가 자가 느끼는 통증 정도에 표시하게 하였다. 지수는 ‘0 10까지로' 0 은 통증 없음 10 에 가까울수록 통증 정 도가 심한 것을 의미한다.

\section{운동프로그램}

바디롤러 운동

바디롤러 운동프로그램은 요가센터에서 주 2회와 집 에서 1회 등 3회/주, $60 \mathrm{~min} / 1$ 회 실행하였다<Table 2>.

Table 2. Body roller and Yoga exercise program

\begin{tabular}{cccc}
\hline Week & BRE. Type & & time(min) \\
\hline \hline $1 \sim 3$ & 1 & Yoga & 60 \\
$4 \sim 6$ & 1,2 & Yoga & 60 \\
$7 \sim 9$ & $1,2,3$ & Yoga & 60 \\
$10 \sim 12$ & $1,3,4$ & Yoga & 60 \\
\hline
\end{tabular}

BRE: Body Roller Exercise

$<$ Figure 4 7>의 Body Roller Exercise Type에 제시 한 바와 같이 소도구 바디롤러 사용을 통한 요부안정 화 운동은 일종의 Balance core exercise로서 근육부위
의 반복적 압박, 정지, 호흡을 통한 자신의 근육 조직 을 롤링자극하는 것이다. 이러한 요법은 통증부위를 중심으로 이루어 졌으며 소도구를 30 60초간 롤링, 정지, 호흡을 반복적으로 실시하였다.

운동부위는 두부의 경우 전두골에서 후두능선까지, 상부는 척추기립근 중심으로, 하부는 후상 장골에서 족저면까지 근육근막의 방향대로 바디롤러를 움직이 면서 운동하였다.

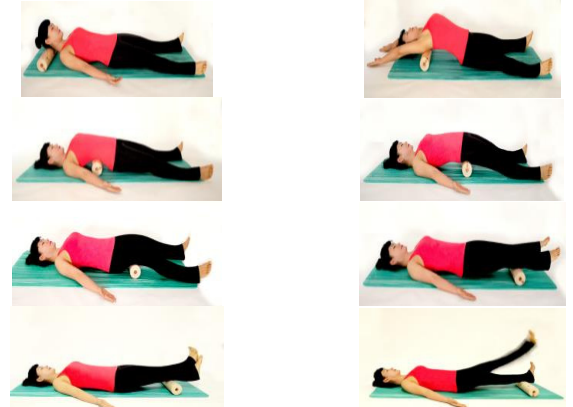

Figure 4. Body Roller Type 1
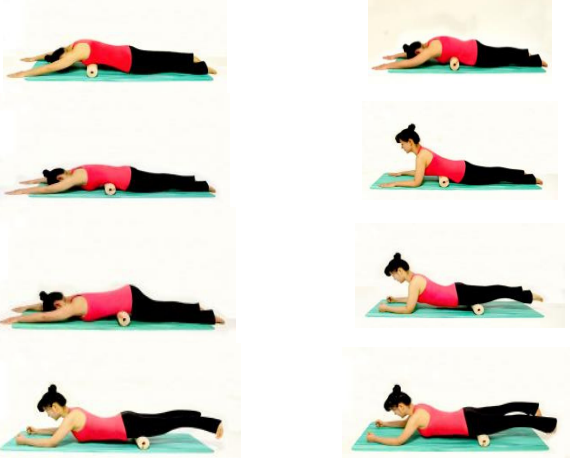

Figure 5. Body Roller Type 2
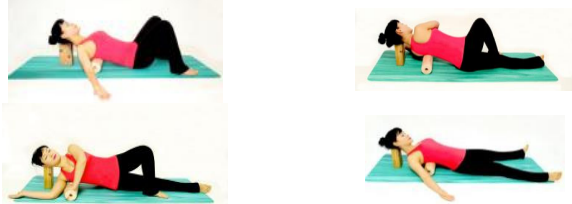

Figure 6. Body Roller Type 3 


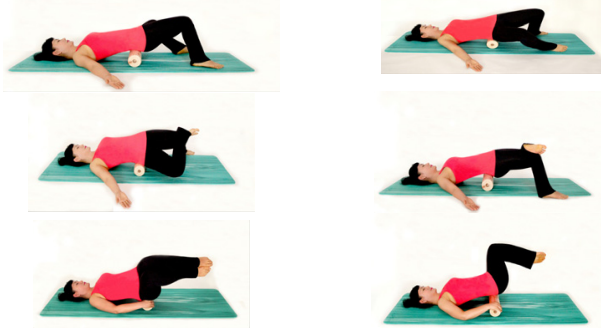

Figure 7. Body Roller Type 4

\section{요가운동}

척추와 관절 가동범위를 넓히기 위한 요가운동은 블릭과 밴드를 이용하여 실시하였으며, 변형된 요가 아사나 트리콘 아사나(Trikonasana), 아도무카시반아사나(Adho Mukha Svanasana), 부장가아사나(Bhujangasana) 숩다파당구스아사 나 1, 2, 3, 4 (Supta Padangusthasana 1, 2, 3, 4), 에카 파 다 라자카포트아사나(Eka Pada Rajakapotasana) 자세를 전 문지도강사의 지도하에 <Figure $8>$ 과 같이 실시하였다.

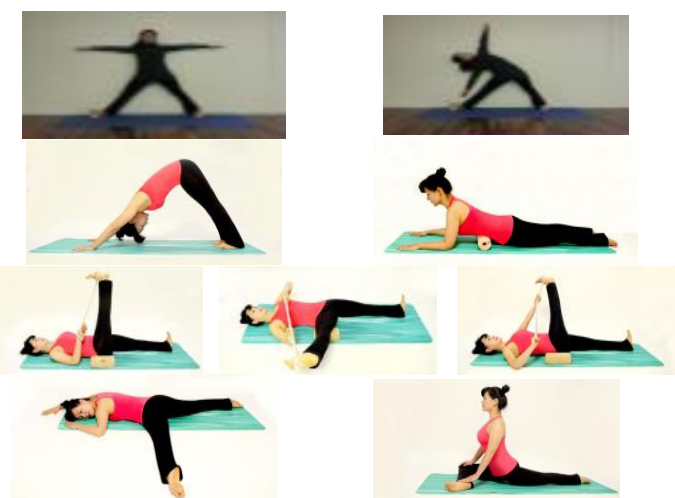

Figure 8. Yoga Exercise Posture

\section{자료처리방법}

본 연구의 자료처리는 SPSS Window Ver.18.0 Program을 이용하여 각 변인의 평균 $(\mathrm{M})$, 표준편차 $(\mathrm{SD})$ 를 산출하고 정규성 및 동질성 검증이 충족되어 반복측정에 의한 이원변량분석(two-way ANOVA by repeated measurement)을 실시하였다. 운동효과의 유 의검증 수준 $(a)$ 은 $p<.05$ 로 설정하였다.
Table 3. Change of physical strength between pre and

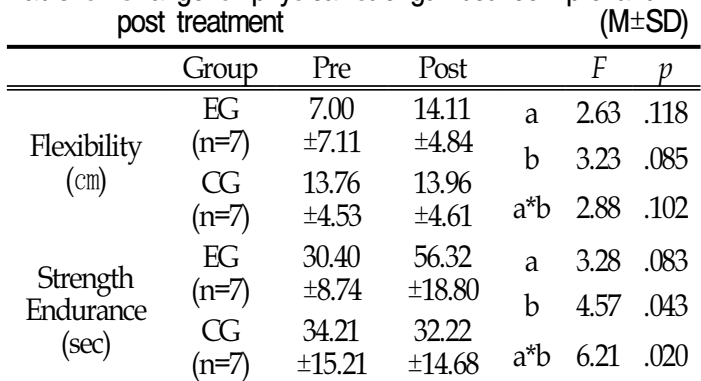

$\mathrm{EG}$; exercise group, $\mathrm{CG}$; control group a; group, b; time, a *b; group * time

\section{결과}

유연성, 근지구력 변화

12 주간의 바디롤러 운동과 요가를 병행처치한 후 운동 및 통제집단의 유연성, 근지구력 변화는 <Table 3>과 같다.

우선 운동집단의 유연성 변화는 사전 $7.0 \mathrm{~cm}$ 에서 사 후 $14.11 \mathrm{~cm}$ 로 두 배 이상 향상되었으나, 통제집단은 사 전, 사후 거의 변화가 없는 것으로 나타났다. 그러나 집단, 시기, 상호작용효과는 없는 것으로 나타났다. 근 지구력은 운동집단이 사전 $30.40 \mathrm{sec}$ 에서 사후 $56.32 \mathrm{sec}$ 로 증가되었으나 통제집단은 사전, 사후 차이가 나타 나지 않았다. 통계검증결과 집단 간 유의차는 나타나 지 않았으나 시기 간 그리고 집단 시기의 상호작용효 과는 통계적으로 유의하게 나타났다 $(p<0.5)$. 상호작용 효과에 대한 사후검증결과 운동집단이 사전에 비해 사 후에 유의하게 높은 것으로 나타났다.

\section{척추변인 변화}

바디롤러 운동과 요가를 실시한 후 요부안정화 변화에 대한 기준인 척추변인의 Cobb's angle, 척추회전각, 좌우 어깨 및 골반 높이를 분석한 결과는 <Table $4>$ 와 같다.

먼저 Cobb's angle은 운동집단이 사전 $9.64^{\circ}$ 에서 사 후 $8.36^{\circ}$ 로 약 $-1.28^{\circ}$ 개선된 것으로 나타났으며, 통제집 단은 사전 $5.43^{\circ}$ 에서 사후 $5.71^{\circ}$ 로 미미한 수준의 척추변 형이 진행된 것으로 나타났다. 통계검증결과 집단간, 시 기간, 집단시기간 상호작용효과 모두 유의하지 않았다. 
척추 회전길이는 운동집단의 경우 사전 $11.29 \mathrm{~mm}$ 에 서 사후 $8.14 \mathrm{~mm}$ 로 $-3.15 \mathrm{~mm}$ 개선된 것으로 나타난 반면, 통제그룹은 사전 $8.29 \mathrm{~mm}$ 에서 사후 $9.71 \mathrm{~mm}$ 로 $1.41 \mathrm{~mm}$ 변 형이 진행된 것으로 나타났다. 통계검증결과 집단 간 의 유의차는 나타났으나, 시기간 및 집단, 시기간의 상호작용 효과는 나타나지 않았다.

어깨기울기는 운동집단의 경우 사전 $5.07 \mathrm{~mm}$ 에서 사 후 $3.57 \mathrm{~mm}$ 로 $-1.5 \mathrm{~mm}$ 개선된 것으로 나타났으나 통제집 단은 사전 $10.14 \mathrm{~mm}$ 에서 사후 $10.43 \mathrm{~mm}$ 로 $0.29 \mathrm{~mm}$ 더 기울 어진 것으로 나타났다. 통계검증결과 집단간에는 유의 한 차이가 나타났으나 시기와 집단시기간 상호작용효 과는 나타나지 않았다.

골반높이는 운동집단이 사전 $6.29 \mathrm{~mm}$ 에서 사후에 $4.29 \mathrm{~mm}$ 로 $-2.0 \mathrm{~mm}$ 정도 개선되었으나, 통제집단의 경우 차이가 나타나지 않았다. 통계검증결과 집단, 시기, 집 단시기간 상호작용효과 모두 유의하지 않았다.

Table 4. Change of variables related vertebral column between pre and post treatment

\begin{tabular}{|c|c|c|c|c|c|c|}
\hline & Group & Pre & Post & & $\bar{F}$ & $\bar{p}$ \\
\hline \multirow{3}{*}{$\begin{array}{c}\text { Cobb's }^{\prime} \\
\text { angle } \\
\left({ }^{\circ}\right)\end{array}$} & EG & 9.64 & 8.36 & a & ב.135 & 7.716 \\
\hline & $(n=7)$ & \pm 3.03 & \pm 2.36 & b & .195 & . \\
\hline & $\begin{array}{c}\text { CG } \\
(\mathrm{n}=7)\end{array}$ & $\begin{array}{c}5.43 \\
\pm 2.50\end{array}$ & $\begin{array}{c}5.71 \\
\pm 2.36\end{array}$ & $a^{*} b$ & 1.38 & .251 \\
\hline \multirow{3}{*}{$\begin{array}{l}\text { Lumbar } \\
\text { spine } \\
\text { rotation } \\
\text { length } \\
\text { (mm) }\end{array}$} & \multirow{2}{*}{$\begin{array}{c}\mathrm{EG} \\
(\mathrm{n}=7)\end{array}$} & \multirow[t]{2}{*}{$\begin{array}{l}11.29 \\
\pm 5.44\end{array}$} & \multirow[t]{2}{*}{$\begin{array}{c}8.14 \\
\pm 4.30\end{array}$} & a & 12.35 & .002 \\
\hline & & & & b & .263 & .613 \\
\hline & $(n=7)$ & $\begin{array}{c}8.29 \\
\pm 5.02\end{array}$ & $\begin{array}{c}9.71 \\
\pm 5.68\end{array}$ & $a^{*} b$ & .649 & .428 \\
\hline \multirow{3}{*}{$\begin{array}{l}\text { Shoulder } \\
\text { slope } \\
\text { (mm) }\end{array}$} & EG & 5.07 & 3.57 & $\mathrm{a}$ & 6.90 & .015 \\
\hline & $(\mathrm{n}=7)$ & \pm 3.40 & \pm 4.76 & b & .072 & .791 \\
\hline & $\begin{array}{l}\text { CG } \\
(\mathrm{n}=7)\end{array}$ & $\begin{array}{l}10.14 \\
\pm 7.99\end{array}$ & $\begin{array}{l}10.43 \\
\pm 6.80\end{array}$ & $a^{*} b$ & .155 & .698 \\
\hline \multirow{3}{*}{$\begin{array}{l}\text { Pelvis } \\
\text { height } \\
(\mathrm{mm})\end{array}$} & EG & 6.29 & 4.29 & $\mathrm{a}$ & 1.33 & .260 \\
\hline & $(\mathrm{n}=7)$ & \pm 1.80 & \pm 1.80 & b & 1.03 & .319 \\
\hline & $\begin{array}{c}\left.{ }_{(n}=7\right) \\
\text { (n) }\end{array}$ & $\begin{array}{c}6.5 / \\
\pm 2.99\end{array}$ & $\begin{array}{c}0.43 \\
\pm 3.95\end{array}$ & $a^{*} b$ & .77 & .387 \\
\hline
\end{tabular}

EG; exercise group, CG; control group $a$; group, $b$; time, $a * b$; group $*$ time

\section{통증자각도 (VAS)의 변화}

앞에 언급한 척추변인은 객관적 자료인 반면에 통 증자각도(VAS)는 연구에 참여한 피험자 개인이 느끼 는 주관적인 통증을 기준으로 나타낸 것으로서 분석된 결과는 <Table $5>$ 와 같다. 객관적인 척주변인 관련 자
료와 마찬가지로 운동처치 전·후간 통증자각도는 운동 집단의 경우 사전 6.32점에서 사후 2.79점으로 통증정 도가 호전된 것으로 나타났다. 반면에 통제집단은 큰 변화가 나타나지 않았다. 통계검증결과 집단간에는 유 의한 차이가 나타나지 않았으나 시기간 $(p<.01)$ 과 그룹 과 시기간의 상호작용 $(p<.001)$ 효과가 나타났다. 상호 작용효과에 대한 사후검증결과 운동집단은 사전에 비 해 사후에 통증정도가 낮아진 것으로 나타났다.

Table 5. Change of VAS between pre and post treatment

$(\mathrm{M} \pm \mathrm{SD})$

\begin{tabular}{ccccccc}
\hline & Group & Pre & Post & & $F$ & $p$ \\
\hline \hline \multirow{4}{*}{ VAS } & \multirow{2}{*}{ EG } & 6.32 & 2.79 & $\mathrm{a}$ & .238 & .630 \\
& & \pm 1.00 & \pm 0.76 & $\mathrm{~b}$ & 18.54 & .000 \\
& \multirow{2}{*}{$\mathrm{CG}$} & 4.99 & 4.57 & & \\
& & \pm 1.50 & \pm 1.44 & $\mathrm{a}$ & \\
& & & & \\
& & &
\end{tabular}

VAS; Visual Analogue Scale

EG; exercise group, CG; control group

a; group, b; time, $\mathrm{a} * \mathrm{~b}$; group * time

\section{논의}

체력의 변화

요추부의 근력약화와 유연성의 퇴행은 허리통증을 유 발하고 각종 스포츠 활동을 포함한 모든 일상생활을 제 한하게 된다. 요추부위 통증으로 일상생활의 제한을 받 는 요통환자에게 권장되는 적절한 운동은 굴곡신전요부 운동, 저항성운동, 슬링운동 등이 제시되고 있다(Kisner et al., 1990; Kim et al., 2010; Park et al., 2005). 따라서 활동적인 일상생활을 지속하기 위해서는 요추부위의 근 육강화운동이 필요한데 최근에는 요부안정화운동이 주 목 받고 있다. 요부안정화운동은 근육의 움직임 조절능 력을 증가시켜 요통유발을 억제하고 일상적인 생활을 가능케 하는데 요추를 받치고 있는 주변의 근조직을 자 극하여 심부및 표면근육의 균형적인 발달을 도모하기 때문인 것으로 보고되고 있다(Sung, 2002).

이러한 의미에서 본 연구에서 바디롤러 운동과 요 가를 병행 실시한 결과, 유연성은 집단과 시기별로 차 이가 나타나지 않았으나 근지구력은 운동집단에서 사 전에 비해 사후에 유의하게 높게 나타났다. 이러한 결 
과는 중년여성 18 명을 대상으로 요부안정화 운동을 실시한 후 유연성과 배근력이 유의하게 증가하였다는 Song et al.(2008)의 보고가 부분적으로 본 연구의 결 과를 뒷받침하고 있다. 또한, 척추협착 원인 요통환자 를 대상으로 천장관절과 요추부위를 간스테드 테크닉 (Gonstead Technique)으로 척추부위 간격을 넓히는 운동을 실시한 결과 유연성과 근력이 증가되었다는 $\operatorname{Park}(2006)$ 의 연구도 본 연구의 결과를 지지하는 근거 로 제시할 수 있다. 그러나 불과 4 회의 카이로프락틱 시행으로 관절가동범위가 증가하였다고 보고한 Jung et al.(2005)의 연구 결과와 차이가 나타나는 것은 적 용프로그램과 수동적 또는 능동적 자극에서 찾을 수 있다. 한편, 본 연구에서 적용한 요부안정화 운동프로 그램이 유연성 개선효과는 나타나지 않았지만 요추부 위의 자극을 통한 근력발달은 근지구력을 증가시킨 것으로 판단된다. 따라서 바디롤러 운동 및 요가를 병 행 실시하여 요통환자들의 요부 근력개선에 도움이 된 결과에서 본 연구의 의미를 찾을 수 있을 것이다.

\section{척추변인의 변화}

척추의 변형에 따른 측만증은 불안정한 폐의 위치로 인해 정상적인 호흡을 하는데 지장을 준다. 이처럼 척 추변형은 요통을 발생시키는 것 외에도 호흡장애를 유 발하기 때문에 이를 개선시키기 위한 다양한 노력이 요 구되고 있다. 특히 운동을 통해 틀어진 체형을 바로 잡 고 근기능을 개선하면 척추의 변형은 물론 호흡 기능을 개선할 수 있다는 보고가 다수 있다(Lehnert-Schroth, 2007). 선행연구에서는 요통과 변형된 요추의 형태를 판단하는 근거로 주로 Cobb's angle의 변화를 분석하였 다. 본 연구에서도 바디롤러운동과 요가를 처치하여 Cobb's angle을 분석한 결과다소 개선되는 경향을 보였 지만 통계적으로 유의하지 않았다. 이러한 결과는 8 주 간의 Medx사 운동기구와 슬링장비를 이용한 요부안정 화 운동 후 Cobb's angle이 유의한 차이가 나타나지 않 았다는 Lee et al.(2012)의 연구결과와 유사하게 나타났 다. 그러나 지금까지 연구된 몇몇 선행연구((Hodges et al., 1997; Kook et al., 2013)의 결과와는 차이가 있는 것이 사실이다. 이는 연구별로 처치된 운동프로그램의
차이에서 기인된 것이 아닌가 생각된다. 본 연구에서 적용한 요가의 아사나 동작은 일반적으로 요통환자에게 적용한 운동프로그램과 크게 다르지 않지만 바디롤러 운동의 경우 연구대상자인 요통환자 스스로 요통부위를 찾아 자극을 가하고 자극에 수반되는 통증을 참아내야 한다는 점에서 연구대상자의 적극적인 참여 여부가 대 단히 중요한데 이러한 부분에서 다소 문제가 있었던 것 으로 생각된다.

척추는 경추, 흥추, 요추와 천추, 미추, 장골, 좌골, 치골을 포함한 골반의 골조직이 분절을 이루는 단일체 로 볼 수 있으며, 골반대(pelvic symphsis)는 고관절, 천장관절, 좌골과 치골의 결합 관절로 구성되어 신체 의 안정성과 운동성을 담보하게 된다(Kim, 1997). 따 라서 척추변형을 정확하게 알기 위해서는 척추의 척추 회전길이나 어깨 기울기, 골반의 높이차 등을 확인하 는 것이 중요하다. 척추변형은 척추 자체가 틀어진 경 우도 있지만 골반이 한쪽 방향으로 틀어지면 천장관절 에 변위가 일어나고 이는 다시 고관절에 변위를 일으 켜 좌우 다리 길이에 차이를 발생시킨다(Kim et al., 2010). 고관절의 각도에 이상이 생기면 척추 측만증과 같은 질환을 유발할 뿐만 아니라 무의식적으로 골반이 높은 방향의 다리를 많이 사용하게 되어 슬관절과 다 리의 변형을 유발하게 된다. 또한, 천장관절에 변형이 생기면 경추, 흥추, 요추, 골반에 복합적인 문제를 발 생시키는데 Park(2002)은 카이로프락틱과 스포츠 마사 지 요법으로 변위가 발생한 부위를 교정하고 처치한 결과 척추변형과 요통이 완화되었다고 보고하였다.

본 연구에서도 척추의 회전길이는 바디롤러 운동요 법과 요가를 처치한 후 평균 $-3.15 \mathrm{~mm}$ 감소하였으며 통 계적인 유의성 검증 결과 집단간에 유의한 차이가 발 견되었다. 이러한 결과는 카이로프락틱과 스포츠마사 지를 통해 변형된 천정관절의 교정을 시도하여 요통, 척추변위 개선과 아울러 천골교정으로 장골의 정상위 치가 환원되었다고 보고한 Park(2002)의 연구결과와 다소 유사하였다. 두 연구에서 실시된 처치방법은 크 게 보면 수동적인 처치와 능동적인 처치라는 점에서 차이가 있지만 효과가 부분적으로 유사하게 나타났다 는 것은 의미가 있다고 할 수 있다.

바디롤러운동과 요가를 처치한 후 척추의 변형에 따른 어깨의 기울기를 분석한 결과 운동집단의 경우 
$-1.5 \mathrm{~mm}$ 감소하였다. 통계적으로 처치시기별로 유의하 게 개선된 결과로 보아, 바디롤러 운동과 요가가 어깨 기울기 변형에 다소 영향을 미친 것으로 볼 수 있다. 그러나 통제집단은 척추기울기기기 다소 더 진행되는 경향을 보였으나 통계적인 유의차는 없는 것으로 나 타났다. 요통은 다양한 원인에서 비롯되는 것이지만 적극적인 치료 및 운동요법을 통해 지속적으로 관리 하는 것이 무엇보다 중요하다고 할 수 있다.

한편 골반높이의 차이에 대한 결과는 집단, 시기, 상호작용 모두 유의하지 않았다. 따라서 바디롤러 운 동요법과 요가의 병행처치는 중년 여성 요통환자의 골반높이의 차이를 개선시키는 데 한계가 있는 것으 로 나타났다. 이는 8 주간 카이로프락틱 처치가 $14 \%$ 의 요추의 교정에 영향을 미쳤다는 Lee(2005)의 보고와 30 40대 14명의 여성요통환자를 대상으로 카이로프락 틱 처치를 한 후 골반변위의 개선에 다소 효과가 있 었다는 Kim et al.(2010)의 연구결과와는 일치하지 않 았다. 따라서 골반변형을 수정하기 위한 요법으로 바 디롤러 운동요법과 요가의 병행처치를 권장하는 것은 한계가 있을 것으로 생각된다.

마지막으로, 통증자각도 (VAS)는 실제 환자가 운동 프로그램 전 후 체감하는 통증정도를 알아보는 것으 로서 시기와 상호작용효과가 유의하게 나타났다. 사후 검증결과 운동집단의 경우 사전에 비해 사후에 평균 적으로 -3.53점 정도 통증지수가 유의하게 감소하였다. 이는 본 연구에서 실시한 바디롤러 운동요법과 요가 의 병행처치가 요통환자들의 심리적 통증정도를 호전 시켰다는 것을 의미하며 본 연구에서 처치한 바디롤 러운동과 요가의 복합 운동프로그램이 요통환자들에 서 긍정적인 효과를 줄 것으로 생각된다.

\section{결론}

본 연구에서 소도구를 이용한 바디롤러 운동과 요가 의 복합 처치가 중년여성 요통환자의 요부근력 안정화 에 필요한 근지구력 개선, 척추 회전길이와 어깨 기울 기에 부분적으로 효과가 있는 것으로 나타났으며, 주관 적 통증지수를 낮춰 주는데 도움이 되는 것으로 판단
된다. 그러나 바디롤러 운동과 아사나 요가의 병행 처 치가 요통환자들의 요부근력 강화의 확실한 도움 여부 는 바디롤러와 변형요가를 개별, 또는 병행 처치그룹으 로 나누어 실행한 결과로 판단하는 것이 좋겠다.

\section{참고문헌}

Cailliet, R. (1995). Low back pain syndrome. Reprint. Originally published: Philadelphia: F. A. Davis.

Danneels, L. A. Vanderstraeten, G. G., Cambier, D. C., Witvrouw, E. E., \& De Cuyper, H. J. (2000). $\mathrm{CT}$ imaging of trunk muscles in chronic low back pain patients and healthy control subjects. European Spine journal, 9(4): 266-272.

Hodges, P. W., \& Richardson, C. A. (1997). Contraction of the abdominal muscles with movement of the lower limb. Physical Therapy, 77(2): 132-144.

Hyun, S. H., Kang, M. S., \& Ryew, C. C. (2012). The effect of vertical traction treatment on lumbar extension muscle strength, spinal curvature and oswestry disability index on chronic back pain patients. The Korean Journal of Physical Education, 51(5): 679-688.

Jung, H. S., Han, S. H., Ham, J. H., \& Kim, H. C. (2005). The effect of chiropractic spinal manipulative therapy on flexion and extension range of motion in lumbar region. Korea Sport Research, 16(3): 391-396.

Jung, Y. K., \& Kim, B. R., \& Kang, S. J. (2006). Effect of low back exercise and resistance training on the flexibility, muscle endurance, lumbar muscle strength and visual analogue scale of the lower back pain patients during 8 weeks. The Official Journal of the Korean Academy of Kinesiology, 8(2): 93-102.

Kook, Y. J., Kim, C. W., \& Lim, J. W. (2013). Effects of trunk muscle strength exercise and deep abdominal muscle stabilization exercise on 
Oswewtry disability, abdominal muscle strength, and deep muscle activity. The Korean Journal of Physical Education, 52(2): 471-481.

Kirkesola, B. S. (2001). A Concept for exercise and active treatment of musculoskeretal disorders. S-E-T article.

Kim, C. W., \& Kim, Y. S. (1996). Characteristic analysis of isokinetic trunk muscle strength in the low back pain patient. The Korea Journal of Sports Medicine, 14(1): 31-39.

Kim, G. S. (2011) The effect of Yoga Asana on the deformation of the lower lims coming from the imbalance of the hip joint and pelvis. International Journal of Complementary Integrative and Alternative medicine, 7(2): 45-58.

Kim, K, T. (1997). Diagnosis and Treatment for Patients with Lumbago. Korean Journal of Family medicine, 18(2): 106-125.

Kim, S. S., \& Kim, M. K. (2007). The Effect of spinal stabilization and extension exercise program for lumbar extensor strength on chronic and post operation low back pain patient. Journal of Coaching Development, 9(1): 165-174.

Kim, Y. H., \& Khil, J. H. (2010). Effect of chiropractic treatment and low back exercise on flexibility, cervical lordosis angle, and pelvic deviation in low back pain patients. The Official Journal of the Korean Academy of Kinesiology. 12(3): 97-106.

Kisner, C. \& Colby, L. A. (1990) Therapeutic Exercise foundation and techniques, Philadelphia: F. A. Davis.

Lee, H. J. (2015) Effects of complex exercise with props on seniors' physical \& psychological condition. [Master's thesis]. University of Seoul.

Lee, K. K., \& Park, J. Y. (2010). The effects of elastic band, Swiss ball, lumbar stabilizing exercise on weight distribution, lumbar strength and pain degree in middle-aged women with chronic lower back. The korea Journal of
Sports Science, 19(3): 1155-1165.

Lee, W. J. (2005). The effect of the lumbar back strength stabilization for chronic lumbargo patients by the sling-exercise and Medx-training during 6weeks. The Korean Journal of Physical Education, 44(5): 485-492.

Lee, W. J., \& Lim, C, H. (2012). Effect of unstale surface lumbar stabilization exercise on trunk posture and balance ability in patients with scoliosis. Journal of the Korean Society of Physical Medicine, 7(1): 59-67.

Lehnert-Schroth, C. (2007). Three-dementional treatment for scoliosis: A Physiotherapeutic method for deformities of the spine. Palo Alto, CA: The Martindale Prese.

Nam, H. C., Chang, C. H., \& Lim, K. I. (2009). Influence of sling stability exercise to have on pain lumbar stability in patients with back pain. Journal of Korean Society of Spine Surgery, 5(1): 37-48.

Park, C, H. (2002). Effect of chiropractic and sports massage in sacroiliac joint subluxation patients. [Master's thesis]. Mokwon University at Daejeon.

Pack, S. H., Sin, M. H., Hwang, E. A., Kang, H. S., \& Kim, H. J. (2009) The effect of sports massage on decrease in low back pain caused by displacement of leg angle and leg length inequality. Korean Academy of Kinesiology, 11(2): 55-63.

Park, G. D. (2006). The effect of gonsted technique and sling-exercise therapy on lumbar back strength and flexibility for patients by chronic low back pain. Journal of Sport and Leisure Studies. 27: 189-201.

Park, G. D., Lee, W. J., \& Park, S. J. (2005). The effect of sling-exercise on lumbar back strength stabilization for lumbar hernia operation patients. Journal of Sport and Leisure Studies. 25: 339-352.

Park, H. S., \& Ham, Y. W. (2009). The effects of 
sling exercise to pain degree and muscle activity degree in low back pain patients. Journal of Sport and Leisure Studies, 36: 655-661.

Shin, Y. A. (2014) Comparison of core stabilizer muscle activity according to movement difficulty and stability during various TRX plank. The Official Journal of the Korean Academy of Kinesiology. 16(4): 31-41.

Sung, H. R., Yang, J. H., Kim, M. S., Kang, M. S., \& Kang, J. S. (2005). Effects of swiss ball exercise on functional fitness and body sway in male elderly nursing home residents. Journal of Physical Growth Motor Development, 13(1): 91-99.
Song, R. Y., \& Ahn, S. H. (2008). Effects of lumbar stabilization exercise on back pain, physical fitness, sleep, and depression in middle-aged women with chronic back Pain. The Journal of Korean Academic Society of Adult Nursing, 20(2): 84-94.

Song, S. H. (2015) The effects of the combined exercise with pilates and yoga on the lumbar muscle strengthening and balance of middle-aged women. [Master's thesis]. Kyung Hee University.

Sung, S. W. (2000) The spinal flexibility and response time of erector spine muscle following stabilization exercise. Journal of Korean Academy of Orthopaedic Manual Therapy, 6(1): 35-49. 